\title{
Status of noise pollution in urban area of Dharan Sub- Metropolitan City and Inaruwa Municipality of Sunsari District, Nepal
}

\author{
Ranij Shrestha ${ }^{1}$, Alankar Kafle ${ }^{2 *}$ and Kul Prasad Limbu ${ }^{3}$ \\ ${ }^{1}$ Sainik Mahavidhyalaya, Dharan, Nepal \\ ${ }^{2}$ Department of Chemistry, Central Campus of Technology, T.U., Dharan, Nepal \\ ${ }^{3}$ Department of Zoology, Post Graduate Campus, T.U., Biratnagar, Nepal \\ E-mail: kalankar@gmail.com
}

\begin{abstract}
The environmental noise level measurement in Dharan and Inaruwa cities of eastern Nepal were conducted and compared with the ambient noise standards provided by Government of Nepal. The noise pollution assessment was performed in autumn and winter seasons by the indicator average day time sound pressure level $\left(\mathrm{L}_{\mathrm{d}}\right.$, during 7.00 to $22.00 \mathrm{hrs}$ ) and average night time sound pressure level ( $\mathrm{L}_{\mathrm{n}}$, during 22.00 to $7.00 \mathrm{hrs}$ ). The $\mathrm{L}_{\mathrm{d}}$ and $\mathrm{L}_{\mathrm{n}}$ values at the commercial, silence and residential zones of Dharan were 78 to 82 and 72 to 73,65 to 73 and 60 to 70,65 to 76 and 62 to 64 $\mathrm{dB}(\mathrm{A})$ in autumn and 78 to 79 and 72 to 76,64 to 71 and 58 to 68,63 to 74 and 60 to $62 \mathrm{~dB}(\mathrm{~A})$ in winter, respectively whereas for Inaruwa, measurement were 75 to 77 and 73 to 75,59 and 57,67 and $60 \mathrm{~dB}(\mathrm{~A})$ in autumn and 66 to 70 and 63 to 68,55 and 53,65 and $58 \mathrm{~dB}(\mathrm{~A})$ in winter, respectively. The results showed that noise levels exceeded the standard value at most of the sites.
\end{abstract}

Key words: Road traffic Sound pollution level, $\mathrm{L}_{\mathrm{d}}, \mathrm{L}_{\mathrm{n}}$,

\section{Introduction}

Noise pollution, a form of environmental air pollution is a threat to human health which is widespread and more severe than ever before. Because of urbanization, increase in population and growth in the use of powerful sources of noise continue to increase in magnitude and severity (Goines et al., 2007). Hearing impairments like temporary and permanent hearing loss may be caused by noise of a high intensity volume. Noise is harmful not only to the behavior, well being and health of human but also affects the behavior and habit of animals (Yong, 2008). Non auditory effects of noise exposure on public health is increasing which leads to annoyance, disturbs sleep and causes daytime sleepiness, increases the occurrence of hypertension, cognitive impairment, physiological stress reactions, endocrine imbalance, and cardiovascular disorders (Babisch, 2011: Basner et al., 2014). In case of chronically exposed to high levels of road or air traffic noise a higher risk of cardiovascular diseases, including high blood pressure and myocardial infarction were suggested by epidemiological studies (Babisch, 2006). Noise can impact on male fertility also which effects testis weight, sperm parameters (count, viability, motility and morphology), sexual hormones, testicular tissue, oxidative stress and finally infertility (Nadri et al., 2016). The most severe non-auditory effect of noise pollution is sleep deprivation or fragmentation which in turn affects the cardiovascular system (Tsaloglidou 
et al., 2015). Now it is recognized that noise pollution is a potential hazard to health, communication and enjoyment of social life and is becoming an indefensible interference and burden upon human comfort. Thus, it is necessary to conduct studies on noise monitoring especially for the vulnerable noisy spots in order to monitor the sound levels and suggest suitable abatement measures for controlling the noise pollution.

\section{Materials and Methods \\ Study area}

Eight measurement sites for Dharan and four sites for Inaruwa were selected for the sound pressure level measurement which were divided into commercial, residential and silence zones (Fig. 1a, 1b).

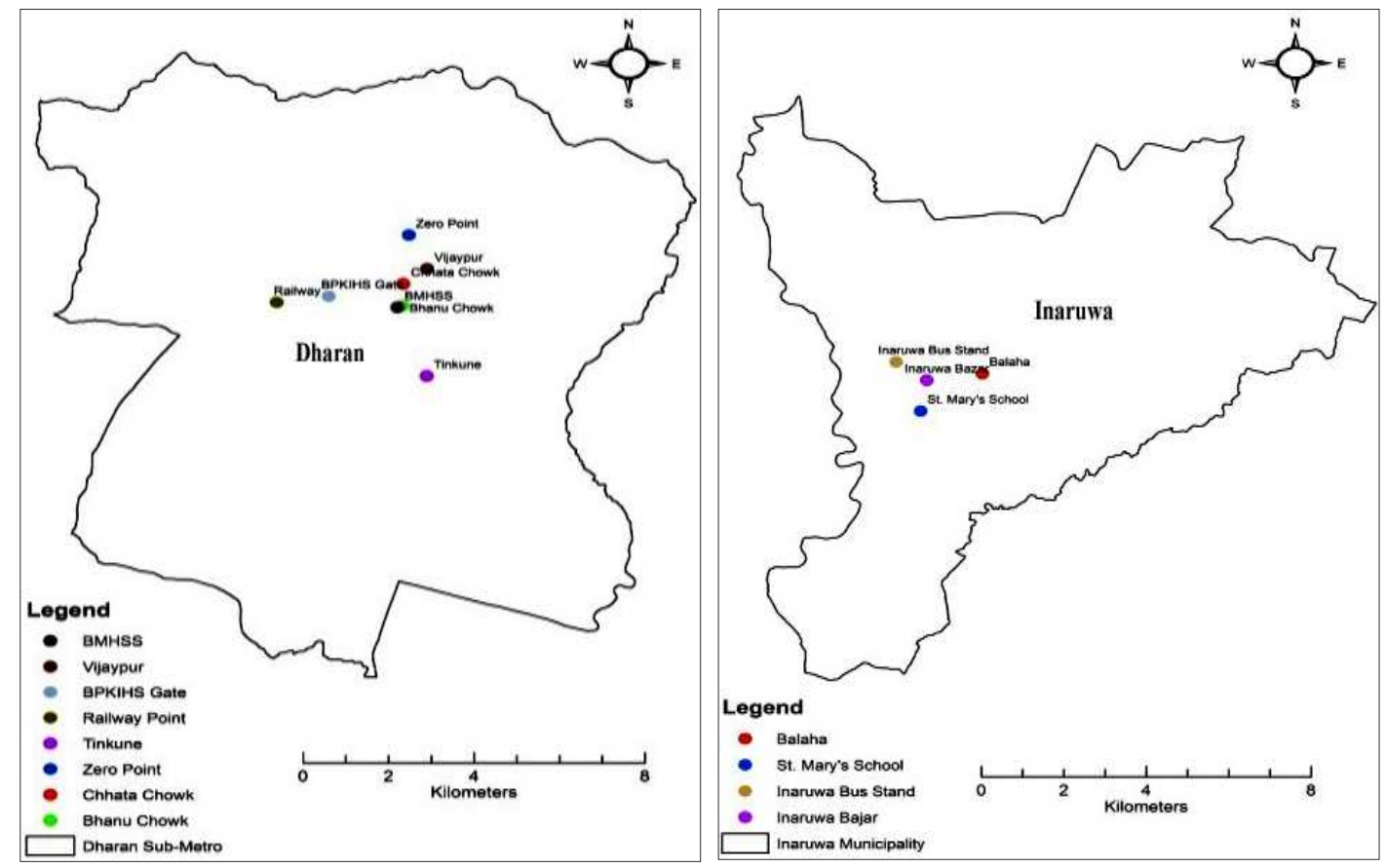

Figure 1. Map of study sites (a) Dharan Sub-metropolitan and (b) Inaruwa Municipality.

\section{Measurement of Sound Pollution Level (SPL)}

Digital sound level meter of model number SL 4010, manufactured by Lutron, Taiwan and calibrated at $94 \mathrm{~dB}(\mathrm{~A})$ was used to record the SPL at different day time zones for instance, early morning, late morning, day time, evening and night time for each sampling sites. There was one set of data for each time zone for each measurement spot representing sound levels recorded at different time zone of the day, which depicts activity related sound level of that area. Such types of measurements were carried out for autumn and winter seasons separately. The data obtained by measurement were evaluated as average day time sound pressure level $\left(\mathrm{L}_{\mathrm{d}}\right.$, during 7.00 to $\left.22.00 \mathrm{hrs}\right)$ and average night time sound pressure level $\left(\mathrm{L}_{\mathrm{n}}\right.$, during 22.00 to $7.00 \mathrm{hrs}$ ). JIS Z 8731/1983(Methods of measurement and description of Aweighted sound pressure level) was followed during the operation and calculation of sound pressure level. The interpretation of noise levels were compared with national standard prescribed by Government of Nepal. 


\section{Results and Discussion}

The potential sources of noise pollution were identified which were mostly vehicle and human activities in both cities. The ambient noise levels, day equivalent level $\mathrm{L}_{\mathrm{d}}$ and night equivalent level $L_{n}$ were observed for all the 12 sites. Furthermore, analysis of two cities noise pollution was also carried to identify the noisy spots by which recommendations can be made for implementation of suitable noise abatement measures.

The results showed that the $L_{d}$ and $L_{n}$ values at the commercial area of Dharan were 78 to 82 and 72 to $73 \mathrm{~dB}(\mathrm{~A})$ in autumn and 78 to 79 and 72 to $76 \mathrm{~dB}(\mathrm{~A})$ in winter which were similar in both monitoring sites and not significant seasonal variation but markedly exceeds the limit value 65 and $55 \mathrm{~dB}(\mathrm{~A})$, respectively (MOSTE, 2012) (Fig. 2a, 2b)
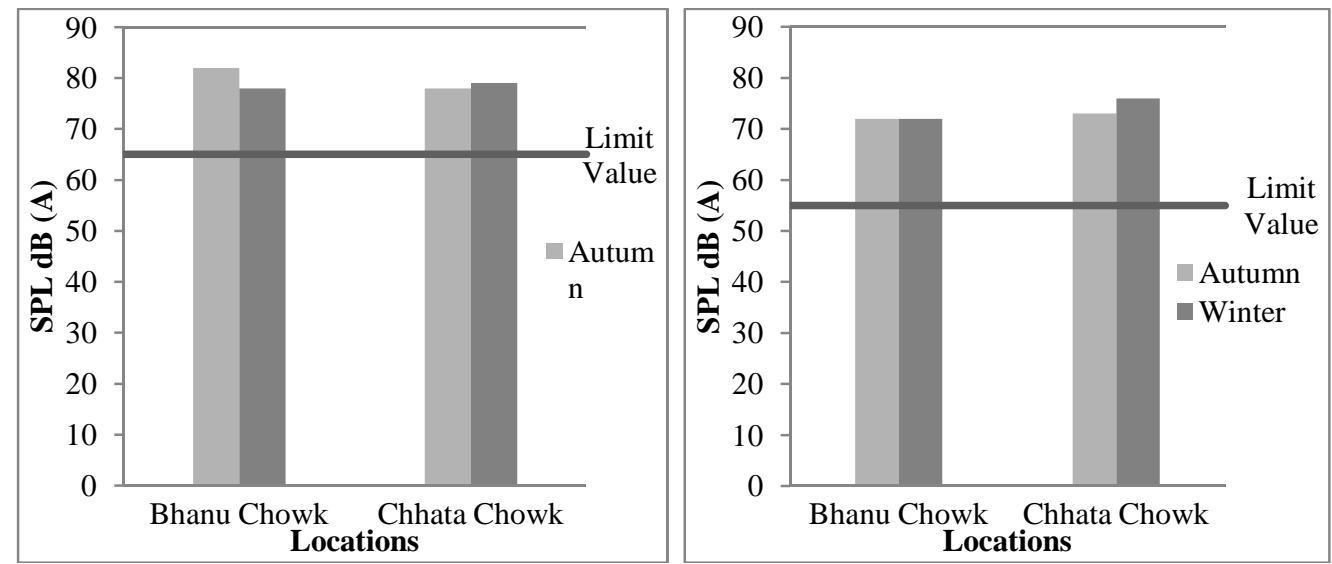

Figure 2. Equivalent sound pressure level in the commercial area of Dharan Submetropolitan City (a) $\mathrm{L}_{\mathrm{d}}$ and (b) $\mathrm{L}_{\mathrm{n}}$

Similarly, $\mathrm{L}_{\mathrm{d}}$ and $\mathrm{L}_{\mathrm{n}}$ for Inaruwa were 75 to 77 and 73 to $75 \mathrm{~dB}(\mathrm{~A})$ in autumn and 66 to 70 and 63 to $68 \mathrm{~dB}(\mathrm{~A})$ in winter, respectively where only $\mathrm{L}_{\mathrm{d}}$ value for winter lies within the standard in Inaruwa Bazar site but other spots facing more noise pollution (Fig. 3a, 3b).
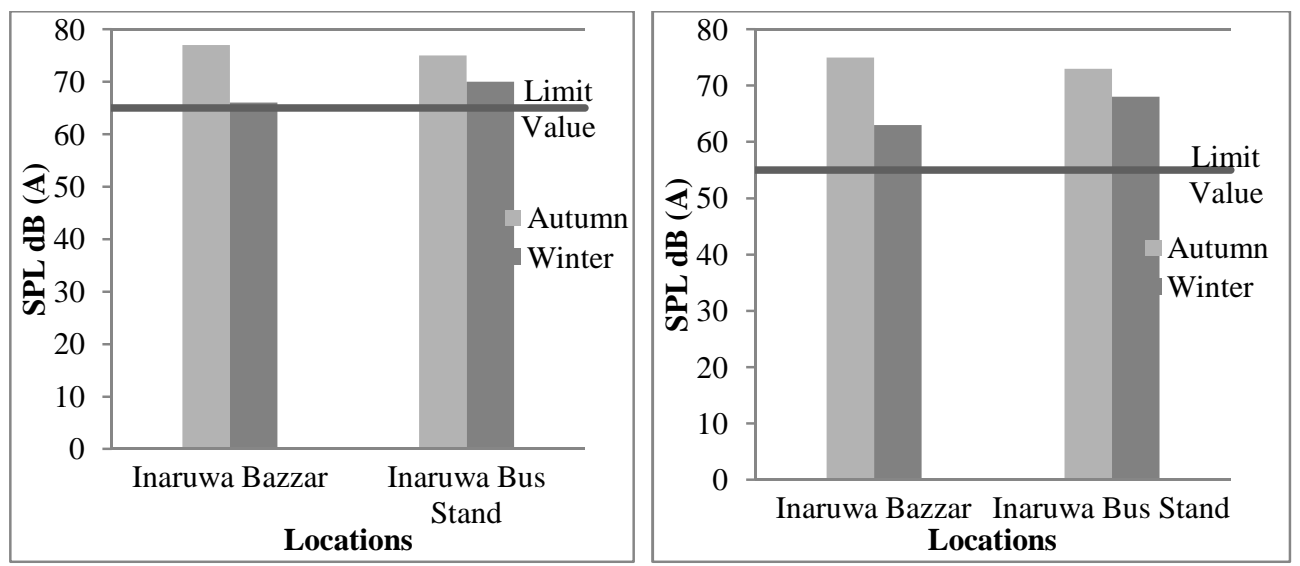

Figure 3. Equivalent sound pressure level in the commercial area of Inaruwa Municipality (a) $\mathrm{L}_{\mathrm{d}}$ and (b) $\mathrm{L}_{\mathrm{n}}$ 
By the comparison with the noise pollution level of Koteshwor, commercial areas of Kathmandu Metropolitan City which has $\mathrm{L}_{\mathrm{d}}$ and $\mathrm{L}_{\mathrm{n}}$ were 81 and $78 \mathrm{~dB}(\mathrm{~A})$, respectively (Kafle \& Maharjan, 2013), Lucknow city 74.8 to 84.2 and 68.2 to $74.9 \mathrm{~dB}(\mathrm{~A})$ (Kisku et al., 2006) and Jharsguda district, Orissa 73 to 83 and 62 to $65 \mathrm{~dB}(\mathrm{~A})$ (Debta et al., 2015) were comparable with the other cities but it is quite different from Delhi where Ld and Ln were 72 to $74 \mathrm{~dB}(\mathrm{~A})$ and 70 to $73 \mathrm{~dB}(\mathrm{~A})$, respectively (Garg et al., 2017).

In the silence zones of both cities the equivalent sound pressure level $\mathrm{L}_{\mathrm{d}}$ and $\mathrm{L}_{\mathrm{n}}$ were 65 to 73 and 60 to $70 \mathrm{~dB}(\mathrm{~A})$ in autumn and 64 to 71 and 58 to $68 \mathrm{~dB}(\mathrm{~A})$ in winter for Dharan. Similarly, $\mathrm{L}_{\mathrm{d}}$ and $\mathrm{L}_{\mathrm{n}}$ for Inaruwa were 59 and $57 \mathrm{~dB}(\mathrm{~A})$ in autumn and 55 and $53 \mathrm{~dB}(\mathrm{~A})$ in winter, respectively (Figs. 4a, 4b) which exceeds the limit value $\left(\mathrm{L}_{\mathrm{d}}\right.$ and $\mathrm{L}_{\mathrm{n}} 50$ and 40 $\mathrm{dB}(\mathrm{A})$, respectively) (MOSTE, 2012) in both seasons which was found quite similar in comparison with its status in Delhi where $L_{d}$ and $L_{n}$ were 51 to $69 \mathrm{~dB}(A)$ and 48 to 60 $\mathrm{dB}(\mathrm{A})$, respectively (Garg et al., 2017) and higher than Jharsguda District, Orissa 44 and 37 $\mathrm{dB}(\mathrm{A})$ (Debta et al., 2015).
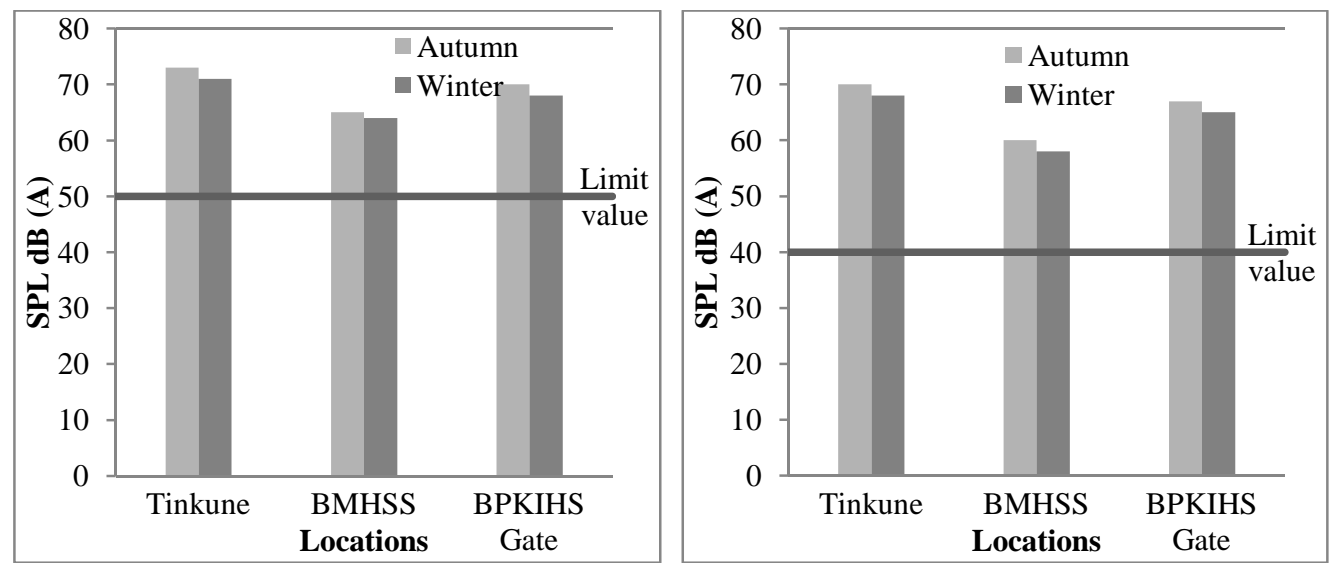

Figure 4. Equivalent sound pressure level in the silence zone of Dharan City (a) $L_{d}$ and (b) $\mathrm{L}_{\mathrm{n}}$
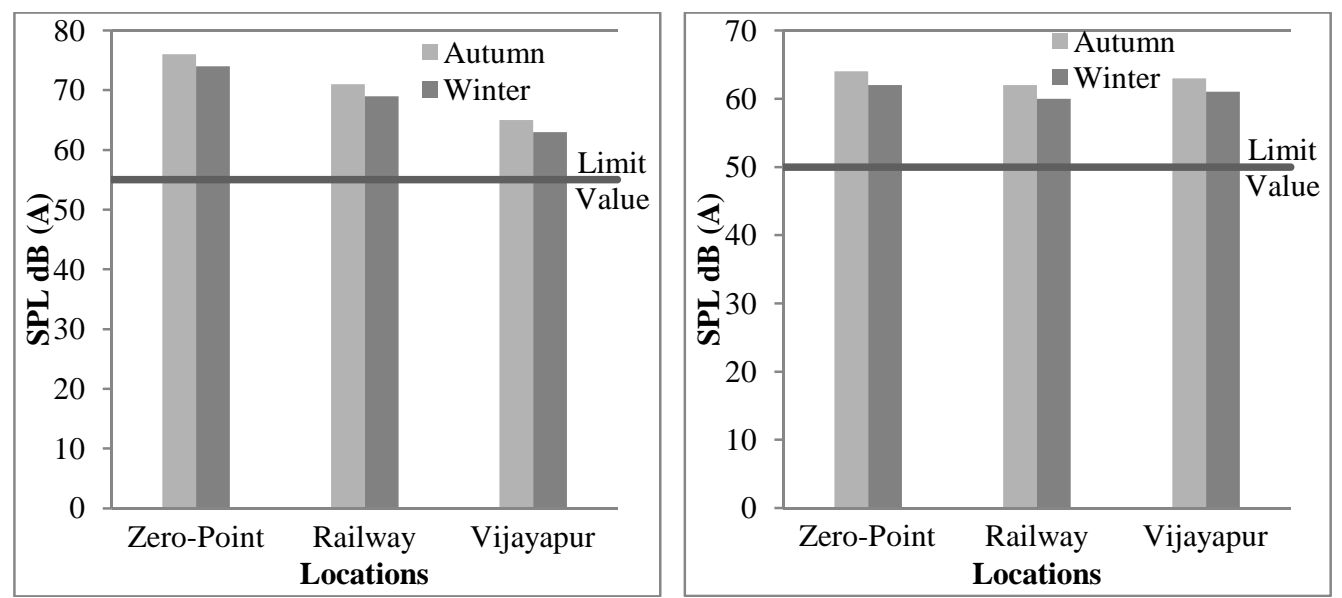

Figure 5. Equivalent sound pressure level in the residential area of Dharan Sub metropolitan City (a) $\mathrm{L}_{\mathrm{d}}$ and (b) $\mathrm{L}_{\mathrm{n}}$ 
The residential areas of both cities were facing more noise pollution than prescribed standard $\left(\mathrm{L}_{\mathrm{d}}\right.$ and $\mathrm{L}_{\mathrm{n}}$ were 50 and $40 \mathrm{~dB}(\mathrm{~A})$, respectively) (MOSTE, 2012) in both seasons. The equivalent sound pressure level $\mathrm{L}_{\mathrm{d}}$ and $\mathrm{L}_{\mathrm{n}}$ were 65 to 76 and 62 to $64 \mathrm{~dB}(\mathrm{~A})$ in autumn and 63 to 74 and 60 to $62 \mathrm{~dB}(\mathrm{~A})$ in winter for Dharan. Similarly, $\mathrm{L}_{\mathrm{d}}$ and $\mathrm{L}_{\mathrm{n}}$ for Inaruwa were 67 and $60 \mathrm{~dB}(\mathrm{~A})$ in autumn and 65 and $58 \mathrm{~dB}(\mathrm{~A})$ in winter, respectively (Figs. 5a,5b, $6 \mathrm{a}, 6 \mathrm{~b})$. It is quite higher than the Indian cities as $\mathrm{L}_{\mathrm{d}}$ and $\mathrm{L}_{\mathrm{n}}$ were 55 to $69 \mathrm{~dB}(\mathrm{~A})$ and 48 to $61 \mathrm{~dB}(\mathrm{~A})$ for Delhi (Garg et al., 2017) and $\mathrm{L}_{\mathrm{d}}$ and $\mathrm{L}_{\mathrm{n}}$ were 63.84 and $54.34 \mathrm{~dB}(\mathrm{~A})$ for Jharsguda District, Orissa (Debta et al., 2015), respectively.
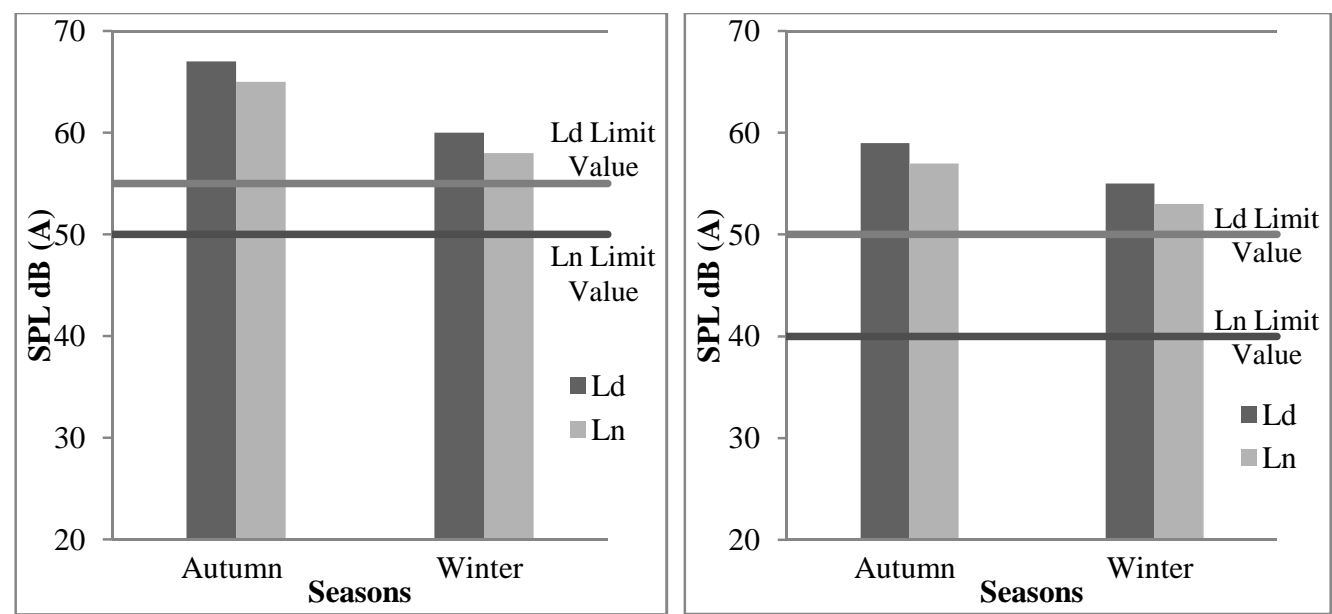

Figure 6. Average day time sound pressure level $\left(\mathrm{L}_{\mathrm{d}}\right)$ and Average night time sound pressure level $\left(\mathrm{L}_{\mathrm{n}}\right)$ (a) Residential area and (b) Silence zone of Inaruwa Municipality

\section{Conclusion}

Environmental noise pollution in both of the cities was mainly due to road traffic activities which had been found above the limit value in most of the monitoring sites. It is being compulsive to prepare and imply the action plan on management of environmental noise pollution with particular emphasis on road traffic noise abatement measures.

\section{References}

Babisch, W. 2006. Transportation noise and cardiovascular risk. Review and synthesis of epidemiological studies, dose-effect curve and risk estimation. (http://www.umweltdaten. de/publikationen/fpdf-1/2997.pdf, accessed 25 November 2017).

Babisch, W. 2011. Cardiovascular effects of noise. Noise Health 13: 201-204.

Basner, M., W. Babisch, A. Davis, M. Brink, C. Clark, S. Janssen \& S. Stansfeld 2014. Auditory and non-auditory effects of noise on health. Lancet 383: 1325-1332.

Debta, N.C., S.K. Naik, N.K. Behera \& A. Mahapatra 2015. Status of noise pollution in and around Jharsuguda urban area. Int. J. Chem. Sci. 13(1): 407-414.

Garg, N., A.K. Sinha, M. Dahiya, V. Gandhi, R.M. Bhardwaj \& A.B. Akolkar 2017. Evaluation and analysis of environmental noise pollution in seven major cities of India. Archives of Acoustics 42(2): 175-188. 
Goines, L. \& L. Haglar 2007. Noise pollution: A modern plague. Southern Medical journal 100(3): 287-293.

Kafle, A. \& M. Maharjan 2013. Comparative study on noise pollution along KoteshworSuryabinayak Extension Road. The Agrineer 5: 19-23.

Kisku, G.C., K. Sharma, M.M. Kidwai, S.C. Barman, A.H. Khan, R. Singh, D. Mishra \& S.K. Bhargava 2006. Profile of noise pollution in Lucknow city and its impact on environment. Journal of Environmental Biology 27(2): 409-412.

MOSTE 2012. National standard for sound quality. Collections of Environmental Standards and Related Notices. Ministry of Science, Technology and Environment, Government of Nepal, 94p.

Nadri, F., A. Khavanin, Z. Mazaheri \& A. Soleimanian 2016. Effect of noise pollution on male fertility (Review). Journal of Occupational Health and Epidemiology 5(1): 53-62.

Tsaloglidou, A., K. Koukourikos, P. Pantelidou, A. Katsimbeli, A. Monios \& L. Kourkouta 2015. Noise pollution as a cardiovascular health hazard. International Journal of Engineering and Applied Sciences 2(11): 82-85.

Yong, E. 2008. City songbirds change their tune. New Scientist, Reed Business Information/Elsevier 197(2649): 33-35. 